\title{
Chemical Modification of Biliprotein Chromophores *
}

\author{
W. Kufer and H. Scheer
}

Institut für Botanik der Universität, Menzinger Straße 67, D-8000 München 19

Z. Naturforsch. 34 c, 776 - 781 (1979); received July 2, 1979

Biliproteins, Phycocyanin, Phytochrome, Chromophore Modification, Dithionite, Reversible Denaturation

The reaction of biliproteins with sodium dithionite has been studied. The reagent is selective towards the chromophores. In denatured phycocyanin from Spirulina platensis, all three chromophores react to form yellow "phycorubin", whereas only $1 / 3$ of the chromophores react in native phycocyanin in a non-statistical manner. From reversion experiments, it can be shown, that the thermodynamic stability of the chromophores towards reaction with dithionite is increased in the native pigment. Similarly, native phytochrome in its $\mathrm{P}_{\mathrm{r}}$ form reacts only partially to a pigment absorbing at both 420 and $660 \mathrm{~nm}$. The same product is formed from native $\mathrm{P}_{\mathrm{fr}}$, indicating both a reversion to $\mathrm{P}_{\mathrm{r}}$ and a partial reduction.

\section{Introduction}

Biliproteins are chromoproteins containing bile pigment chromophores (A-dihydrobilins [2-6], e. g. formulas 1,2 ) covalently linked via a thioether bond to the apoprotein $[7-10]$. The phycobiliproteins (phycocyanins (PC), allophycocyanins and phycoerthyrins) are the main light harvesting pigments of photosystem II of the blue-green, red and cryptophytan algae [11-13]. As has been shown by denaturation studies, the physical and chemical properties of the phycobiliprotein chromophores, which fit them for their biological functions, are profoundly influenced by noncovalent interactions with the protein moieties ("molecular ecology"). Native phycobiliproteins are highly fluorescent and transfer the absorbed energy to the photosynthetically active reaction center chlorophyll by the mechanism of induced fluorescence (see [14] for references). This fluorescence is completely quenched by denaturation [15]. Also, the main absorption band for denatured phycobiliproteins is in the near uv spectral region, but the native forms have their main absorption band in the red spectral region [1], a prerequisite for effective photosynthesis of the algae at their natural habitat. Similarly pronounced differences between the native and denatured pigments exist in phytochro$m e$ [16], the photomorphogenetic reaction center pigment of higher plants and some algae [17]. It under-$$
\text { [1]. }
$$

* Studies on Plant Bile Pigments 5 - Part 4 of this series

Abbreviations: $\mathrm{PC}$, phycocyanin; $\mathrm{P}_{\mathrm{r}}, \mathrm{P}_{\mathrm{fr}}$, phytochrome in the red and far-red absorbing from, respectively.

Reprint requests to Dr. H. Scheer.

0341-0382/79/0900-0776 \$01.00/0

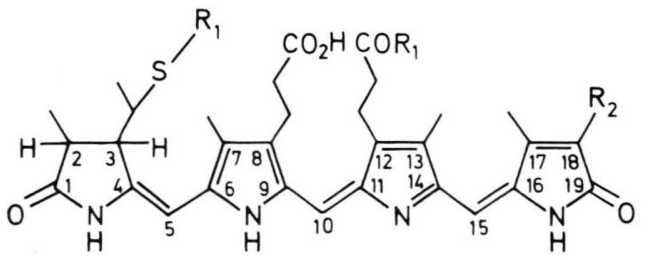

Formula 1:

PC: $\mathrm{R}_{1}=$ Protein, $\mathrm{R}_{2}=$ Ethyl

$\mathrm{P}_{\mathrm{r}}: \mathrm{R}_{1}=$ Protein, $\mathrm{R}_{2}=$ Vinyl

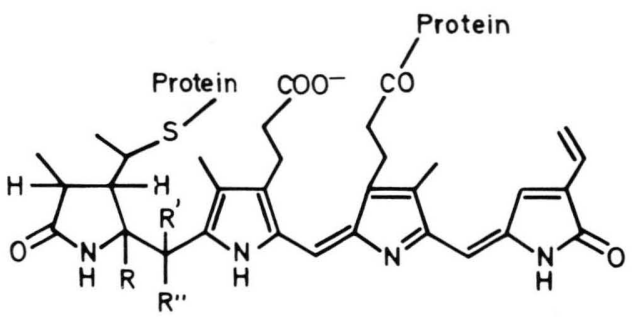

Formula 2: $\mathrm{P}_{\mathrm{fr}}$

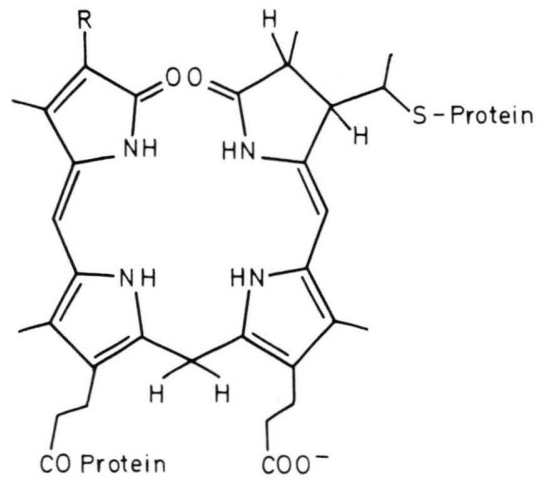

Formula 3:

Phycorubin: $\mathrm{R}=$ Ethyl

Phytochromorubin: $\mathrm{R}=$ Vinyl 
goes photochemical conversion from $\mathrm{P}_{\mathrm{r}}$ to $\mathrm{P}_{\mathrm{fr}}$, the physiologically active form, only in the native state. An approach to study the noncovalent interactions between chromophores and apoproteins in the biliproteins responsible for the changes cited above more precisely, was made by the method of selective chemical modification of the bile pigment chromophore.

By comparison of the properties of the thus obtained "synthetic" chromophore, when the apoprotein is in its native or denatured form, respectively, a better insight of the influence of the protein moiety on the chromophore is expected. For the first experiment of this type, the reductant dithionite was chosen as a chromophore selective reagent. Interestingly, dithionite (and other reductants) have been shown earlier to accelerate the in vitro dark reversion of $\mathrm{P}_{\mathrm{fr}}$ to $\mathrm{P}_{\mathrm{r}}[18]$.

\section{Materials and Methods}

PC was isolated from Spirulina platensis. The deep-frozen cells $(30 \mathrm{~g})$ were broken with glass beads $(0.17 \mathrm{~mm} \varnothing)$ in a cell mill, and the debris was extracted twice with $50 \mathrm{ml}$ tris-buffer $(10 \mathrm{~mm}$, $\mathrm{pH}$ 8.0). The resulting crude extract was centrifuged at $78,000 \times g$ for $60 \mathrm{~min}$. The protein was purified by chromatography on DEAE-cellulose (DE 52, Whatman, England) and subsequent gel filtration on Biogel P 150 (Biorad, California). $E_{620 / 280}=4.2$.

Phytochrome was isolated from oat using a modified procedure [19] of the method described by [16]. It had a purity index $E_{280 / 660}=20$ and a molecular weight of 60,000 . Work with phytochrome was done under green safety light.

PC was denatured by adding $200 \mu$ l of a stock solution in phosphate buffer to $2.0 \mathrm{ml}$ of urea buffer ( $8 \mathrm{M}$ urea, $50 \mathrm{~mm}$ phosphate $\mathrm{pH} 7.5$ ), yielding a final concentration of $9 \times 10^{-6} \mathrm{M}$ in phycocyanobilin chromophores. Phytochrome (final concentration $3 \times 10^{-6} \mathrm{M}$ in phytochromobilin chromophores, calculated from the extinction coefficient of [20]) was denatured by addition of solid urea $(8 \mathrm{M})$ to its solution in tris-buffer $(10 \mathrm{~mm}, \mathrm{pH} 7.4)$. For reduction, the denatured pigments were treated with solid sodium dithionite $\left(5 \times 10^{-3} \mathrm{M}\right)$, or aliquots of a freshly prepared solution of dithionite in phosphate buffer were added (final concentration $5 \times 10^{-4} \mathrm{M}$ ). PC was renatured by removal of urea by gel filtration on a $1.7 \times 12 \mathrm{~cm}$ Biogel P 2 column equilibrated with phosphate buffer. This procedure was carried out either in the absence ("aerobic renaturation") or in the presence of $5 \times 10^{-3} \mathrm{M}$ dithionite ("anaerobic renaturation"). Native biliproteins were treated with dithionite as described for the denatured forms.

UV-vis spectra were recorded on a DMR 22 spectrophotometer (Zeiss, Oberkochen). The phytochrome measurements were performed with a UVP 300 spectrophotometer (Shimadzu, Japan) equipped with a DBC-2 baseline correction unit in the doublebeam mode.

\section{Results}

Phycocyanin: If denatured $\mathrm{PC} *$ was treated with sodium dithionite, the bands at 602 and $355 \mathrm{~nm}$ disappeared, and a new band arose at $418 \mathrm{~nm}$ (Fig. 1 a). A spectroscopically identical reaction product was obtained, if $5 \times 10^{-4} \mathrm{M}$ or $5 \times 10^{-3} \mathrm{M}$ dithionite were used, but the reaction was faster with the latter concentration (decrease from $20 \mathrm{~min}$ to $10 \mathrm{sec}$ onds for completion at room temperature).

If the yellow product (denatured, dithionitetreated PC) was renatured by removal of urea (gel filtration on biogel P 2) in the absence of dithionite ("aerobic renaturation") (Fig. 1 b) or at a dithionite conc. of $5 \times 10^{-4} \mathrm{M}$, the blue colour of native $\mathrm{PC}$ reappeared. The product was identical to native PC as judged from its uv-vis spectroscopic and electrophoretic properties. If the renaturation procedure was carried out in the presence of $5 \times 10^{-3} \mathrm{M}$ dithionite ("anaerobic renaturation", Fig. 1 b), the resulting pigment had absorption bands at both $620 \mathrm{~nm}$ and $418 \mathrm{~nm}\left(E_{620} / E_{418}=3: 1\right)$. If this greenish-blue pro-

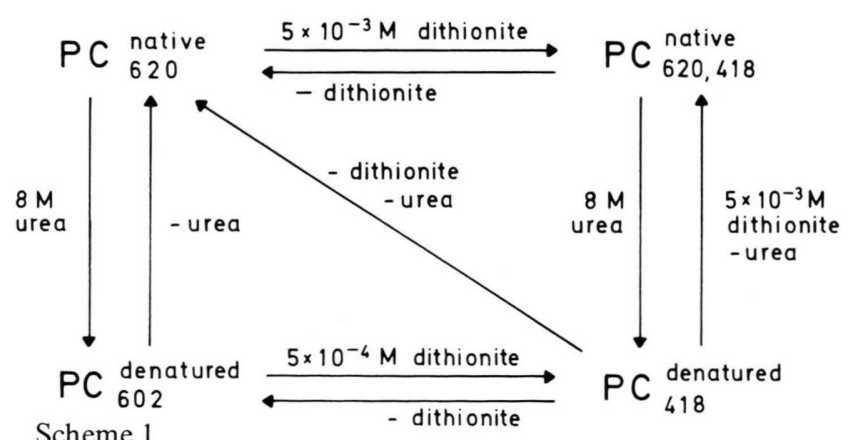

Scheme 1

* The results obtained with PC are summarized in Scheme 1 , those for phytochrome in Scheme 2 and Table I. The subscripts for the pigments refer to the approximate maxima of their visible absorption bands, the surscripts to the state of the protein. 

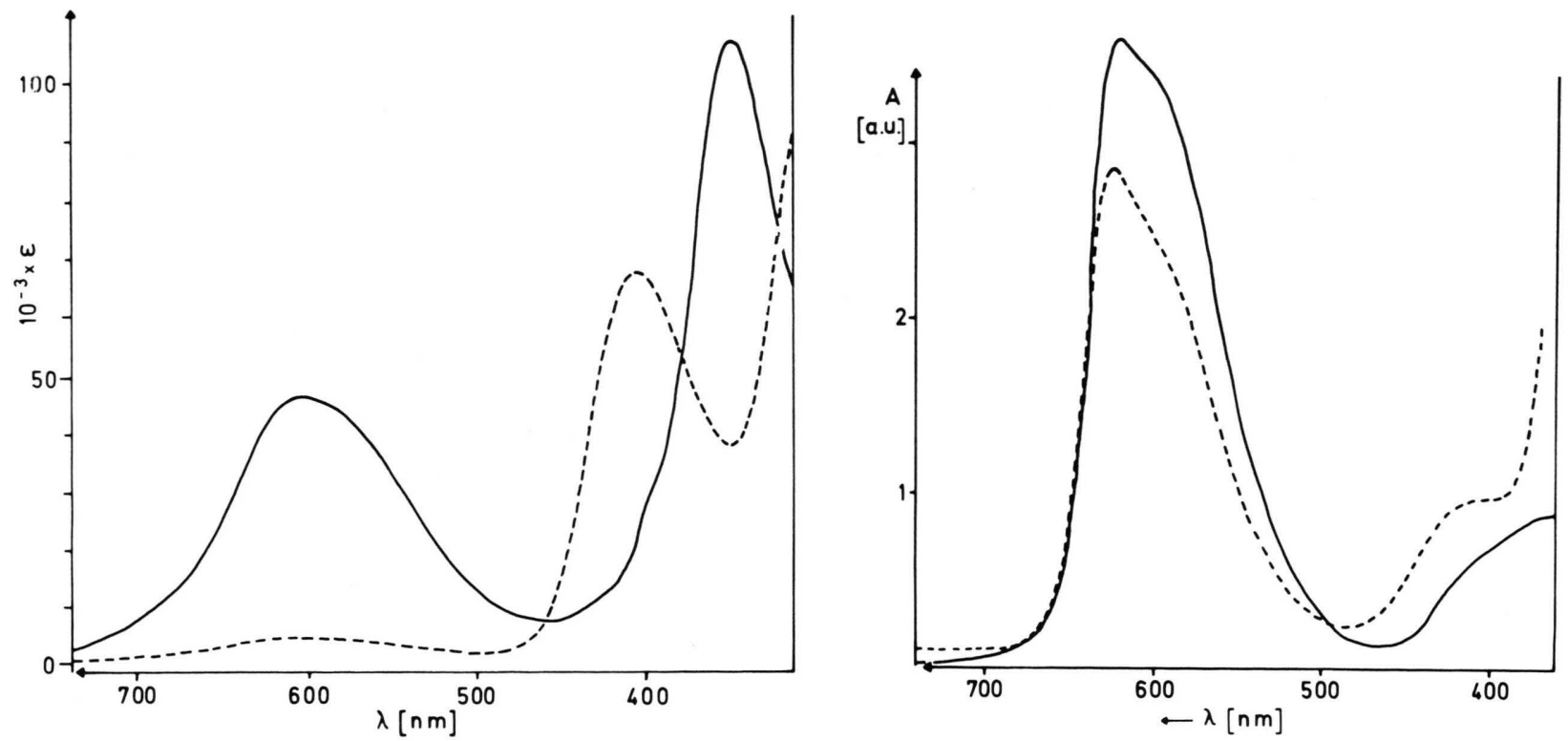

Fig. 1. Uv-vis spectra of the products shown in Scheme 1. a) $\mathrm{PC}_{602}^{\text {denatured }}(-$ ): Denatured $\mathrm{PC}$ in phosphate buffer $(0.05 \mathrm{M}), \mathrm{pH} 7.5$, containing urea $(8 \mathrm{M})$; $\mathrm{PC}_{418}^{\text {denatured }}(-----)$ : The same solution after addition of sodium dithionite $\left(5 \times 10^{-3} \mathrm{M}\right)$. b) $\mathrm{PC}_{620}^{\text {native }}(-)$ : $\mathrm{PC}_{418}^{\text {denatured }}$, renatured by removal of urea and dithionite by gel filtration. $\mathrm{PC}_{620}^{\text {native }}{ }_{418}$ $(-----): \mathrm{PC}_{418}^{\text {denatured }}$ after removal of urea only by gel filtration in the presence of dithionite $\left(5 \times 10^{-3} \mathrm{M}\right)$.

duct was denatured again by addition of solid urea $(8 \mathrm{M})$ without further addition of dithionite, the yellow colour returned immediately, the absorption spectrum showing a single peak in the visible region at $\lambda_{\max }=418 \mathrm{~nm}$. No bleaching of the $620 \mathrm{~nm}$ band was seen, when native $\mathrm{PC}$ was treated with $5 \times 10^{-4} \mathrm{M}$ dithionite. At a concentration of $5 \times 10^{-3} \mathrm{M}, E_{620}$ decreased by $26 \%$ (the integrated intensity of the long wavelength band by $35 \%$ ) and a peak at $418 \mathrm{~nm}$ appeared. Spectroscopically the pigment obtained this way resembled that of the "anaerobic renaturation" procedure.

Phytochrome *: After denaturation of $\mathrm{P}_{\mathrm{r}}$ by addition of urea to a final concentration of $8 \mathrm{M}$, the original band at $660 \mathrm{~nm}$ was shifted to $655 \mathrm{~nm}$ and de-

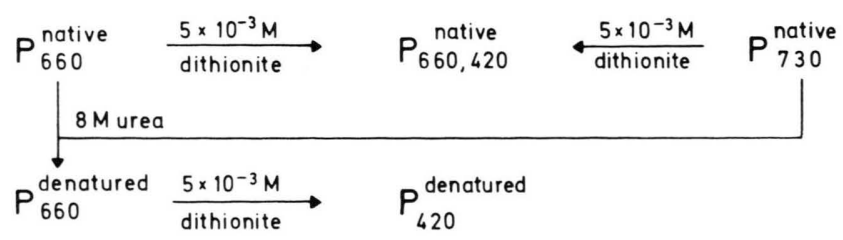

Scheme 2

* See footnote p. 3. creased to $27 \%$. Dithionite treatment $\left(5 \times 10^{-3} \mathrm{M}\right)$ of the denatured $\mathrm{P}_{\mathrm{r}}$ resulted in total bleaching of the long wavelength band and the apperance of a band at $422 \mathrm{~nm}$. These changes were also seen in the difference spectrum $\left(\mathrm{P}_{\mathrm{r}}\right.$ denatured $/ 5 \times 10^{-3} \mathrm{M}$ dithionite minus $\mathrm{P}_{\mathrm{r}}$ denatured) showing a positive band at $430 \mathrm{~nm}$ and a negative one at $655 \mathrm{~nm}$. Denaturation of $\mathrm{P}_{\mathrm{fr}}$ in the free base form resulted in conversion to $P_{r}$, as has been described earlier [16], and therefore, the products resulting from dithionite treatment were identical to those obtained for $\mathrm{P}_{\mathrm{r}}$. Addition of $5 \times 10^{-3} \mathrm{M}$ sodium dithionite to native $\mathrm{P}_{\mathrm{r}}$ yielded only partial bleaching of the band at $660 \mathrm{~nm}$. The uv-vis difference spectrum $\left(\mathrm{P}_{\mathrm{r}}\right.$ native $/ 5 \times 10^{-3} \mathrm{M}$ dithionite minus $\mathrm{P}_{\mathrm{r}}$ native) had negative bands at $660 \mathrm{~nm}$ (and $730 \mathrm{~nm}$ ) and a positive band at $433 \mathrm{~nm}$. From this difference spectrum, a decrease of the original $E_{660}$ by $10-15 \%$ was calculated. Native $\mathrm{P}_{\mathrm{fr}}$ showed uv-vis absorption bands at 660 and $720 \mathrm{~nm}$. Upon treatment with $5 \times 10^{-3} \mathrm{M}$ dithionite, the band at $720 \mathrm{~nm}$ disappeared, the absorption band at $660 \mathrm{~nm}$ increased by about $40 \%$, and a new band was formed at $425 \mathrm{~nm}$, corresponding to a negative band at 720 and two positive bands at 655 and $430 \mathrm{~nm}$ in the difference spectrum $\left(\mathrm{P}_{\mathrm{fr}}\right.$ native $/ 5 \times 10^{-3} \mathrm{M}$ dithionite minus $\mathrm{P}_{\mathrm{fr}}$ native) (Fig. 2). 
Table I. Uv-vis spectra of the phytochrome reduction experiments with dithionite.

\begin{tabular}{|c|c|c|c|c|c|c|}
\hline \multirow[t]{3}{*}{ Compound } & \multicolumn{4}{|c|}{ Uv-vis absorption spectra } & \multirow{3}{*}{$\begin{array}{l}\text { Extrema in the uv-vis } \\
\text { difference spectra } \\
\text { (II minus I) } \\
\lambda_{\max }[\mathrm{nm}]\end{array}$} & \multirow{3}{*}{$\begin{array}{l}\text { Intensity change of the } \\
\text { long wavelength } \\
\text { bands after dithionite- } \\
\text { treatment, calculated } \\
\text { from uv-vis absorption } \\
\text { and uv-vis absorption } \\
\text { difference spectra }\end{array}$} \\
\hline & \multicolumn{2}{|l|}{ Original (I) } & \multicolumn{2}{|c|}{$\begin{array}{l}\text { after treatment with } \\
5 \times 10^{-3} \mathrm{M} \text { dithionite (II) }\end{array}$} & & \\
\hline & $\lambda_{\max }[\mathrm{nm}]$ & $E^{\text {a }}$ & $\lambda_{\max }[\mathrm{nm}]$ & $E^{\mathrm{a}}$ & & \\
\hline $\mathrm{P}_{\mathrm{r}}$, native & $\begin{array}{l}660 \\
730\end{array}$ & $\begin{array}{l}0.2 \\
0.01\end{array}$ & $\begin{array}{l}660 \\
b\end{array}$ & 0.18 & $\begin{array}{l}660 \text { neg. } \\
730 \text { neg. } \\
433 \text { pos. }\end{array}$ & $\begin{array}{l}10-15 \% \text { decrease }^{a} \\
100 \% \text { decrease }\end{array}$ \\
\hline $\mathrm{P}_{\mathrm{r}}$, denatured & 655 & 0.06 & 422 & 0.08 & $\begin{array}{l}655 \text { neg. } \\
430 \text { pos. }\end{array}$ & $100 \%$ decrease \\
\hline $\mathrm{P}_{\mathrm{fr}}$, native & $\begin{array}{l}660 \\
720\end{array}$ & $\begin{array}{l}0.07 \\
0.06\end{array}$ & $\begin{array}{l}660 \\
425\end{array}$ & $\begin{array}{l}0.1 \\
0.06\end{array}$ & $\begin{array}{l}655 \text { pos. } \\
720 \text { neg. } \\
430 \text { pos. }\end{array}$ & $\begin{array}{c}40 \% \text { increase } \\
100 \% \text { decrease }\end{array}$ \\
\hline
\end{tabular}

${ }^{a}$ Quantification of the results was difficult for some samples, due to turbidity and bleaching of the background absorption by the dithionite.

$\mathrm{b}$ At $\lambda<430 \mathrm{~nm}$ undetermined due to the turbidity of the sample.

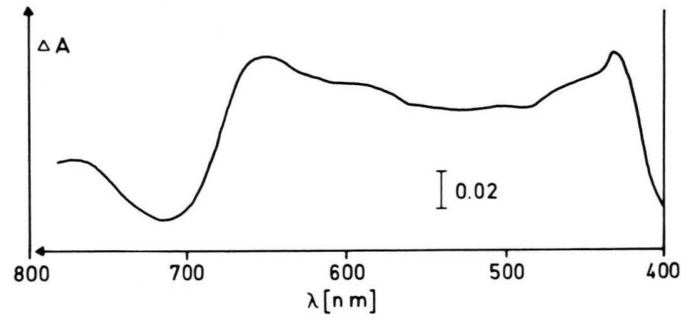

Fig. 2. Uv-vis difference spectrum of the reaction of phytochrome $\mathrm{P}_{\mathrm{fr}}$ with $5 \times 10^{-3} \mathrm{M}$ sodium dithionite. $\mathrm{P}_{\mathrm{fr} \text {, native }} /$ sodium dithionite minus $\mathrm{P}_{\mathrm{fr}}$ native .

\section{Discussion}

Denatured $\mathrm{PC}$ or $\mathrm{P}_{\mathrm{r}}$ could be completely converted to yellow pigments with sodium dithionite. Fischer and Plieninger [21] have reported, that biliverdin is reduced by this reagent to bilirubin. A rubinoid pigment $\left(\lambda_{\max }=420 \mathrm{~nm}\right)$ has been obtained, too, from phycocyanobilin [22]. The reduction products of PC and $\mathrm{P}_{\mathrm{r}}$ had absorption maxima (418 and $422 \mathrm{~nm}$, respectively) as expected for rubins $(400-460 \mathrm{~nm})$, e. g. [21, 23]. Assuming a similar reduction by dithionite as has been reported for biliverdin [21], an A-dihydro-(meso)-bilirubin structure is suggested for these pigments (formula 3), which we have named "phycorubin" and "phytochromorubin".

Treatment of native biliproteins led only to partial reaction, even at a dithionite concentration of $5 \times 10^{-3} \mathrm{M}$, exceeding ten times the concentration sufficient for complete reduction of the denatured forms $\left(5 \times 10^{-4} \mathrm{M}\right)$. From their uv-vis spectral data, the products obtained at $c_{\text {dithionite }}=5 \times 10^{-3} \mathrm{M}$ contain verdin-type chromophores (formula 1) as well as rubin-type chromophores (formula 3). From the decrease of the intergrated intensity of the long wave-length band of $35 \%$, it can be estimated, that about one third of the phycocyanin chromophores are in the reduced state. A non-statistical reduction of the three chromophores present in the PC monomer is supported by the uv-vis difference spectrum ( $\mathrm{PC}$ native minus $\mathrm{PC}$ native $/ 5 \times 10^{-3} \mathrm{M}$ dithionite), which has a negative double band at 596 and $616 \mathrm{~nm}$ (blue-shifted with respect to the absorption maximum of native PC at $620 \mathrm{~nm}$ ), as well as by the fluorescence excitation spectra $*$ of partially reduced $\mathrm{PC}$, which do not exhibit the short wavelength shoulder present at $600 \mathrm{~nm}$ in native PC. Thus, the chromophores absorbing at shorter wavelengths are preferentially reduced.

Several explanations may principally be given for the different behavior of denatured and native biliproteins. The protein could shield the chromophores from the aqueous environment and thus prevent the attack of the reductant, or, the activation energy for the reduction of the chromophores could be enhanced in the native as compared to the denatured

* In collaboration with Dr. A. Holzwarth from the Institut für Strahlenchemie at the Max-Planck-Institut für Kohlenforschung, Mülheim/Ruhr, to be published. 
state. If these kinetic arguments would hold, the yellow chromophores would have to be accomodated by the protein.

However, these kinetic arguments are not in agreement with the results of the renaturation of "phycorubin". During renaturation at $c_{\text {dithionite }}=5 \times 10^{-4} \mathrm{M}$, complete reoxidation occured. At $c_{\text {dithionite }}=5 \times 10^{-3} \mathrm{M}$ ("anaerobic renaturation"), the chromophores were still reoxidized to the most part, and only $20-30 \%$ remained reduced, if judged by the uv-vis spectrum (Fig. $1 \mathrm{~b}$ ). The renaturation products thus resemble those obtained by dithionite treatment of the native PC at the corresponding concentrations. Any artefact due to possible losses of dithionite by air-oxidation during the chromatography could be excluded by a subsequent denaturation of the renaturation products. Without further addition of dithionite, fully reduced "phycorubin" was obtained back. This proves, that reoxidation to the corresponding cyanin had occured under conditions thermodynamically favoring the reduced chromophores in denatured PC.

The results can, therefore, only be explained by a thermodynamic argument, e. g. a stability difference of the biliprotein chromophores towards reaction with dithionite between the native and the denatured state. If the dithionite reaction is a true reduction to rubins (hydrogenation of $\mathrm{C}-10$ and $\mathrm{N}-22$ ), this would implicate, that the redox potential of the chromophores must be more negativ in the native than in the denatured state. This stability difference towards reduction may be correlated to the recently suggested conformational change from the cyclic form in the denatured, to the extended conformation in the native chromoprotein [1]. This possibility is currently investigated by reduction studies on suitable model compounds. A decreased stability towards oxidation has also been found for square planar complexes of bilirubin with metals like $\mathrm{Zn}^{2+}$, and the effect has been correlated to conformational changes [24].

[1] H. Scheer and W. Kufer, Z. Naturforsch. 32 c, $513-519$ (1977).

[2] W. J. Cole, D. J. Chapman, and H. W. Siegelman, J. Amer. Chem. Soc. 89, 3643 - 3645 (1967).

[3] W. Rüdiger, P. O'Carra, and C. O'hEocha, Nature 215, 1477 - 1478 (1967)

[4] D. J. Chapman, W. J. Cole, and H. W. Siegelman, J. Amer. Chem. Soc. 89, 5976 - 5977 (1967).

[5] H. L. Crespi and J. J. Katz, Phytochemistry 8, $759-761$ (1969).
By treatment of native and denatured $\mathrm{P}_{\mathrm{r}}$ with dithionite, analogous results were obtained as with the respective forms of PC. Denatured $\mathrm{P}_{\mathrm{r}}$ was fully reduced, while only partial reduction of native $\mathrm{P}_{\mathrm{r}}$ was observed at $c_{\text {dithionite }}=5 \times 10^{-3} \mathrm{M}$. In contrast to PC, however, attempts to renature urea denatured phytochrome by gel filtration failed. Though a kinetic argument can, therefore, not yet be unequivocally excluded in this case, one may suggest a similar stability change of the native $\mathrm{P}_{\mathrm{r}}$ chromophore towards reduction by analogy with PC.

An acceleration of the in vitro dark reversion of $\mathrm{P}_{\mathrm{fr}}$ by reductants like dithionite, $\mathrm{NADH}$ and ferredoxin has been described by Mumford and Jenner [18]. Under the conditions used in this study, treatment of native $\mathrm{P}_{\mathrm{fr}}$ with $5 \times 10^{-3} \mathrm{M}$ dithionite led to complete conversion to the partially reduced $\mathrm{P}_{\mathrm{r}}$ form within $10 \mathrm{~min}$, the time required to take a spectrum. Mumford and Jenner [18] have speculated about some kind of a reduced intermediate during the interconversion. From the experiments described, it may be suggested, that the $\mathrm{P}_{\mathrm{r}}$ is produced from $\mathrm{P}_{\mathrm{fr}}$ via a bilirubin - like species. Kinetic studies are in advance to clarify this proposal.

\section{Acknowledgements}

This work was supported by a grant of the Deutsche Forschungsgemeinschaft. We thank Prof. W. Rüdiger for continuing support and helpful discussions. A sample of purified phytochrome was kindly provided by Mr. C. Harzer and Mr. T. Brandlmeier. The authors acknowledge a generous gift of Spirulina platensis by Prof. C. Soeder, Gesellschaft für Strahlenforschung, Dortmund. We thank Ms. C. Bubenzer for skilful technical assistance in the preparation of PC. We thank the Kontron Technik $\mathrm{GmbH}$, Eching, as the local agent of Shimadzu for providing a UVP 300 photometer with a DBC- 2 correction unit for the phytochrome measurements.

[6] H. Scheer, Z. Naturforsch. 31 c, $413-417$ (1976).

[7] H.-P. Köst, W. Rüdiger, and D. J. Chapman, Liebigs Ann. Chem. 1975, 1582 - 1593 (1975).

[8] E. Köst-Reyes, H.-P. Köst, and W. Rüdiger, Liebigs Ann. Chem. 1975, 1594 - 1600 (1975).

[9] S. Schoch, G. Klein, U. Linsenmeier, and W. Rüdiger, Liebigs Ann. Chem. 1976, 549 - 558 (1976).

[10] G. Klein, S. Grombein, and W. Rüdiger, Hoppe-Seyler's Z. Physiol. Chem. 358, 1077 - 1079 (1977). 
[11] L. Bogorad, Ann. Rev. Plant. Physiol. 26, 396-401 (1975).

[12] W. Rüdiger, Ber. Dtsch. Bot. Ges. 88, $125-139$ (1975).

[13] E. Gantt, Photochem. Photobiol. 26, 685 - 689 (1977).

[14] J. Grabowski and E. Gantt, Photochem. Photobiol. 28, 39 - 46 (1978).

[15] R. F. Murphy and P. O'Carra, Biochem. Biophys. Acta 214, 371 - 373 (1970).

[16] S. Grombein, W. Rüdiger, and H. Zimmermann, Hoppe-Seyler's Z. Physiol. Chem. 356, 1709 - 1714 (1975).

[17] L. H. Pratt, Photochem. Photobiol. 27, 81-105 (1978).
[18] F. E. Mumford and E. L. Jenner, Biochemistry 10, $98-101$ (1971).

[19] T. Brandlmeier, Diploma Thesis, Universität München, 1977.

[20] F. E. Mumford and E. L. Jenner, Biochemistry 5, 3657 - 3662 (1966).

[21] H. Fischer and H. Plieninger, Hoppe-Seyler's Z. Physiol. Chem. 274, 231 - 260 (1942).

[22] H. L. Crespi, U. Smith, and J. J. Katz, Biochemistry 7, $2232-2242$ (1968).

[23] C. C. Kuenzle, Biochem. J. 119, 395 - 409 (1970).

[24] J. D. Van Norman and R. Szentirmay, Anal. Chem. 46, $1456-1464$ (1974). 